\title{
ENTRE LA CREENCIA RELIGIOSA Y LA VOLUNTAD POLÍTICA: UN ESTUDIO COMPARADO DE LOS FILMS TODO ES AUSENCIA (1984), DE RODOLFO KUHN, Y EN NOMBRE DE DIOS (1987), DE PATRICIO GUZMÁN
}

Between Religious Belief and Political Will: A Comparative Study of the Films Todo es ausencia (1984), by Rodolfo Kuhn, and En nombre de Dios (1987), by Patricio Guzmán

Paola Margulis ${ }^{\mathrm{a}}$

Conicet / Universidad de Buenos Aires

DOI: https:// doi.org/ 10.15366/ secuencias2017.45.003

\begin{abstract}
RESUMEN
El presente artículo se propone establecer un análisis comparado de dos films que entablan, de algún modo, un diálogo entre sí: Todo es ausencia (Rodolfo Kuhn, 1984) y En nombre de Dios (Patricio Guzmán, 1987). Se trata de dos documentales realizados por cineastas latinoamericanos exiliados para Televisión Española hacia la década de los ochenta, los cuales tematizan el vínculo que la Iglesia católica mantuvo con las cúpulas de poder y con la causa popular durante las dictaduras militares que afectaron a Argentina y Chile en las décadas de los setenta y ochenta. En términos específicos, el artículo intentará analizar el tratamiento fílmico que estos documentales plantearon sobre la represión, las relaciones institucionales —especialmente las que vinculan a la Iglesia católica一, las modalidades de intervención sobre el espacio público y las tipologías de resistencia en ambos países vecinos. En especial, nos interesaremos por el tipo de materiales de los que se nutre cada documental -testimonios, metraje de archivo, registro, etc-y su respectivo peso dramático. A partir de un recorrido por estos ejes de análisis, el presente artículo aspira a proponer una mirada comparada en torno a los modos de construcción y elaboración del pasado dictatorial en Argentina y en Chile.
\end{abstract}

Palabras clave: cine, documental, dictadura, transición democrática, Chile, Argentina.

[a] Paola Margulis es doctora en Ciencias Sociales por la Universidad de Buenos Aires. Se desempeña como investigadora en el Consejo Nacional de Investigaciones Científicas y Técnicas (CONICET). Es docente de Historia de los Medios de Comunicación en la Facultad de Ciencias Sociales de la Universidad de Buenos Aires, donde además codirige el Área de Estudios sobre Comunicación y Documental Audiovisual. Sus líneas de investigación abarcan los estudios sobre documental, las transiciones políticas y tecnológicas y las problemáticas de archivo. Es autora del libro De la formación a la institución. El documental audiovisual argentino en la transición democrática (1982-1990) (2014). 


\begin{abstract}
The present article aims to establish a comparative analysis of two films which, in a way, partake in a dialogue: Todo es ausencia (Rodolfo Kuhn, 1984) and En nombre de Dios (Patricio Guzmán, 1987). These two documentaries, made by exiled Latin American filmmakers for Televisión Española during the 1980s, focus on the link held by the Catholic Church with the highest spheres of power, as well as with the «popular cause», during the military dictatorships that affected Argentina and Chile in the decades of 1970 and 1980. In specific terms, the article will attempt to analyze the cinematographic treatment that these documentaries offer about repression, institutional relations - especially those involving the Catholic Church-, modes of intervention in public spaces, and the typologies of resistance in these neighboring countries. In particular, we are interested in the kind of materials that nourish each documentary -testimonies, archive footage, film registers, etc. -and their respective dramatic effect. By way of tour through these analytical axes, the present article aspires to propose a comparative view around the modes of construction and elaboration of the dictatorial past in Argentina and Chile.
\end{abstract}

Keywords: cinema, documentary, dictatorship, transition to democracy, Chile, Argentina.

\section{Introducción}

El presente artículo propone establecer un análisis comparado de dos films que entablan, de algún modo, un diálogo entre sí. O por lo menos, la iniciativa de uno de ellos nace como respuesta al estado de situación que plantea el otro. Según narra Jorge Ruffinelli:

Entre marzo y mayo de 1986, Patricio Guzmán viajó a Chile con el propósito de filmar una película sobre las relaciones entre el Estado y la Iglesia Católica. El proyecto provenía de tres años antes, cuando Guzmán vio Todo es ausencia, un documental de Rodolfo Kuhn sobre los «desaparecidos» en Argentina, que comentaba sobre la conducta pasiva y hasta cómplice de la Iglesia en su país. La diferencia con lo que sucedía en Chile saltaba tanto a la vista que, de inmediato, se convirtió en un gran tema cinematográfico ${ }^{1}$.

Todo es ausencia (Rodolfo Kuhn, 1984) y En nombre de Dios (Patricio Guzmán, 1987) abordan las desesperadas luchas por resistir bajo los regímenes dictatoriales que oprimieron a la Argentina (1976-1983) y a Chile (19731989) respectivamente, focalizando en las relaciones que la Iglesia católica mantuvo con las cúpulas de poder, por un lado, y con los movimientos sociales involucrados en la lucha, por otro.
[1] Jorge Ruffinelli, El cine de Patricio Guzmán. En busca de las imágenes verdaderas (Santiago de Chile, Uqbar editores, 2008), p. 143. 


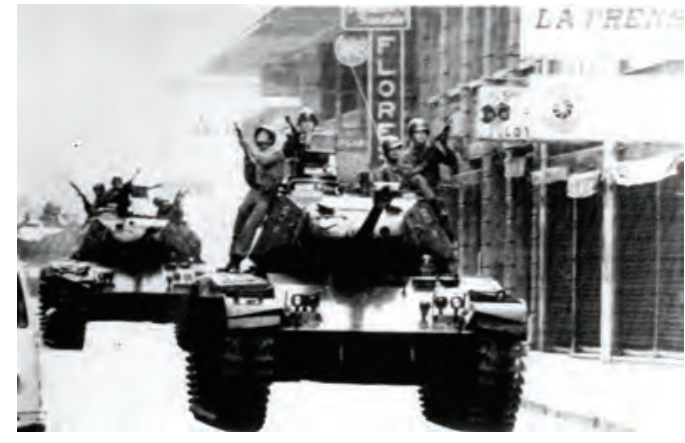

La Batalla de Chile

(Patricio Guzmán, 1975-1979).

Los dos documentales fueron realizados durante la misma época por cineastas exiliados para Televisión Española (TVE), institución que hizo manifiesta su oposición a los regímenes dictatoriales que afectaban, por aquel entonces, a países latinoamericanos, sirviendo de «refugio» para distintos realizadores en el destierro. En 1983, al cumplirse diez años del golpe militar en Chile, el canal español anunció que «se suma a la condena del régimen pinochetista y la petición para el restablecimiento de las libertades democráticas, emitiendo la película La batalla de Chile» ${ }^{2}$, compromiso que también se traslada a la producción de documentales de denuncia, como aquellos objeto del presente análisis.

El documental argentino del exilio —sostiene J avier Campo, recuperando la reflexión de Emilio Crenzel- presenta una transformación de las narrati-

[2] Alberto Elena y Mariano Mestman, «Para un observador lejano: el documental latinoamericano en España», en Paulo Antonio Paranaguá (ed.), Cine documental en América Latina (Madrid, Cátedra, 2003), p. 91.

[3] Javier Campo, Batallas estéticas reales. Tendencias formales y temáticas en el cine documental político argentino (1968-1989), Tesis Doctoral (Buenos Aires, Universidad de Buenos Aires, 2014), p. 246.

[4] José Miguel Palacios, «Chilean Exile Cinema and its Homecoming Documentaries», en Rebecca Prime (Ed.), Cinematic Homecomings. Exile and Return in Transnational Cinema (Nueva York y Londres, Bloomsbury, 2015), pp. 147-168.

[5] Zuzana M. Pick, «Chilean Cinema in Exile, 1973-1986», en Michael T. Martin (ed.), Latin American Cinema, volume 2 (Detroit, Wayne State University Press, 1997), pp. 423-440.

[6] Marina Díaz López, «Patricio Guzmán», en Paulo Antonio Paranaguá (ed.), Cine documental en América Latina (Madrid, Cátedra, 2003), p. 216. vas revolucionarias en prácticamente su opuesto: las narrativas humanitarias. Según sostiene el autor, «...los films realizados desde 1979 no solo dejarán de lado los años previos al golpe, sino también las décadas anteriores. Su recorrido histórico comenzará el 24 de marzo de 1976 y será narrado casi exclusivamente por los testimoniantes... $\gg^{3}$. El cine chileno del exilio excede por mucho la producción argentina. J osé Miguel Palacios entiende esta cinematografía como una formación transnacional sostenida en las redes globales de solidaridad política ${ }^{4}$. Al respecto, Zuzana M. Pick nota que el apoyo internacional le brindó a los exiliados chilenos la posibilidad de mantener un sentido de cohesión nacional ${ }^{5}$.

En lo que se refiere puntualmente a los films de Kuhn y Guzmán, notamos que, además de abordar temáticas afines, estos documentales poseen otras características en común. Ambos evidencian una textura de imagen similar y plantean interrogantes compatibles. Desde el punto de vista formal, los dos apelan a un estilo convencional, proponiendo narraciones lineales que se ajustan a una modalidad expositiva y recurriendo, en general, a encuadres estáticos en las entrevistas y en los testimonios. Si bien orientados hacia la caracterización del trabajo de Guzmán durante su «etapa española» en TVE, algunos de los comentarios de Marina Díaz López también describen adecuadamente el film de Kuhn, entendiendo que sus formas «...buscan una mirada codificada de cine documental de calidad, pero también de producción televisiva» ${ }^{6}$. Sin embargo, y más allá de estos puntos en común, también las diferencias entre estos films aparecen fácilmente a la vista. Mientras que Todo es ausencia se apoya en la voice over para guiar pedagógicamente la narración —recurriendo a un elaborado trabajo de puesta en escena en algunas entrevistas-, En nombre de Dios construye un tipo de narración enarbolada a partir de la información que van aportando los testimonios. Por otra parte, 
la propia coyuntura de Chile durante el rodaje -la efervescencia en las calles, la protesta y la represión - posiblemente haya influido en las características del registro y el ritmo del film de Guzmán, el cual, aún lejos de la intensidad de La batalla de Chile (Patricio Guzmán, 1975-1979) logra, sin embargo, por momentos, una dinámica agitada, marcada por el uso dramático de la banda sonora, el punto de vista inestable y los álgidos movimientos de cámara como consecuencia de las persecuciones policiales, los bruscos acercamientos y alejamientos del objetivo, el corte directo, etc.

Precisamente por abordar la misma problemática y por proponer una estilística bastante similar, la puesta en relación de estos dos films permite advertir con mayor claridad algunos aspectos que aluden a la especificidad histórica y a las características puntuales que adquirieron distintivamente los regímenes dictatoriales en Chile y Argentina. El presente artículo intentará analizar el tratamiento fílmico que estos documentales plantearon sobre la represión, las relaciones institucionales - especialmente las que vinculan a la Iglesia católica-, las modalidades de intervención sobre el espacio público y las tipologías de resistencia en ambos países vecinos. En especial, nos interesaremos por el tipo de materiales de los que se nutre cada documental - testimonios, metraje de archivo, registro, etc.- y su respectivo peso dramático.

Orquestada desde el exilio, la finalización de Todo es ausencia coincide con el regreso de la democracia en Argentina ${ }^{7}$, siendo este uno de los primeros films documentales «del retorno ${ }^{8}{ }^{3}$ junto a Cuarentena. Exilio y regreso (Exil und Rückkehr, Carlos Echeverría, 1983), Las madres de Plaza de Mayo (Susana Blaustein Muñoz y Lourdes Portillo, 1985) y la trilogía de J orge Denti La Argentina que está sola y espera (J orge Denti, 1986) ${ }^{9}$ - en comenzar a denunciar el terrorismo de Estado y en difundir la lucha por parte de los organismos de derechos humanos por lograr la recuperación de los desaparecidos y el juzgamiento de los culpables de los crímenes de lesa humanidad. Aun cuando hacia el retorno democrático la peor parte del horror estaba llegando a su fin, dicho período también está signado por la incertidumbre, la ambigüedad y las continuidades con el régimen dictatorial ${ }^{10}$.

Por su parte, la dictadura chilena fue más extensa en el tiempo, y el film de Guzmán, apenas posterior al de Kuhn, coincide con sus últimos años de desarrollo. En el caso chileno, la denuncia vehiculizada a través del cine comenzó a manifestarse mucho antes, y los referentes son variados, impulsados tanto desde el interior de dicho país como desde el exilio —constituyendo aquello que Zuzana Pick llamó «el cine de la resistencia» ${ }^{11}$ - . A partir de 1983, cuando se produce en Chile la primera apertura del régimen para aceptar el ingreso de exiliados, algunos realizadores, entre ellos Raúl Ruiz, lograron introducirse en dicho país para filmar ${ }^{12}$. Dicho año también marca un punto de inflexión en el curso de la vida política y social de Chile, verificándose un incremento en la protesta ${ }^{13}$, situación que tiene un correlato en la captura de imágenes audiovisuales para documentales y noticieros alternativos. Entre los films que abordan los horrores de la dictadura chilena y la problemática del destierro
[7] El estreno de Todo es ausencia en España tuvo lugar en diciembre de 1985, casi un año antes que se exhibiera el film ficcional El señor Galíndez (1984), también de Rodolfo Kuhn.

[8] J anet Walker, «Rights and Return: Perils and Fantasies of Situated Testimony after Katrina», en Bhaskar Sarkar y Janet Walker (eds.), Documentary Testimonies. Global Archives of Suffering (Nueva York y Oxon, Routledge, 2010). Tomamos el concepto de documental «del retorno» del trabajo de Janet Walker, el cual pone el acento en el regreso al lugar geográfico en el cual el trauma tuvo lugar. En el caso de los films analizados, el retorno no solamente alude a la figura del entrevistado, sino también de los realizadores, que vuelven a sus países a filmar.

[9] Dicha trilogía está compuesta por los cortos Pampa del infierno, Entre el cielo y la tierra y No al punto final (Mariano Mestman, «Al compás de la revuelta. J orge Denti más allá del cine y la televisión», en Catálogo del XI Festival DerHumAlc, Cine de Derechos Humanos [Buenos Aires, FICDH, 2009]).

[10] Claudia Feld y Marina Franco, «Introducción», en Claudia Feld y Marina Franco (dirs.), Democracia, hora cero: actores, políticas y debates en los inicios de la posdictadura (Buenos Aires, Fondo de Cultura Económica, 2015), p. 11.

[11] Zuzana Pick, «Chilean Documentary: Continuity and Disjunction», en Julianne Burton (ed.), The Social Documentary in Latin America (Pittsburgh, University of Pittsburgh Press, 1990), p. 118.

[12] Jacqueline Mouesca, El documental chileno (Santiago de Chile, LOM Ediciones, 2005), p. 99.

[13] Germán Liñero Arend, Apuntes para una historia del vídeo en Chile (Santiago, Ocho Libros Editores, 2010). 
[14] Emilio Crenzel, La historia política del Nunca más. La memoria de las desapariciones en la Argentina (Buenos Aires, Siglo Veintiuno Editores, 2008), p. 32.

[15] Shoshana Felman, «Education and Crisis», en Cathy Caruth (Ed.), Trauma: Explorations in Memory (Baltimore, The J ohns Hopkins University Press, 1995).

[16] Antonio Traverso, «Dictatorship Memories: Working through Trauma in Chilean Postdictatorship Documentary», en Continuum: Journal of Media $\&$ Cultural Studies (vol. 24, n. ${ }^{\circ}$ 1, febrero de 2010), pp. 179-191.

[17] Gustavo Aprea, «Los usos de los testimonios en los documentales audiovisuales argentinos que reconstruyen el pasado reciente», en Gustavo Aprea (comp.), Filmar la memoria. Los documentales audiovisuales y la re-construcción del pasado (Los Polvorines, Universidad Nacional de General Sarmiento, 2012), pp. 121-152.

[18] Conviene recuperar aquí la separación que Gustavo Aprea realiza entre testimonio y entrevista. Según explica el autor, la diferencia pasa por el rol que se le atribuye al entrevistado y al testimoniante. A diferencia del entrevistado, que es interrogado en función de sus conocimientos sobre un tema - en calidad de experto o de testigo- sin que se enfatice su subjetividad, el testimoniante justifica su presencia en función de la transmisión de una experiencia en la que participó como protagonista u observador privilegiado. En la medida en que evoca aspectos personales, hay en él una voluntad que de ningún modo podría ser forzada (Gustavo Aprea, «El lugar de los testimonios en los documentales argentinos contemporáneos», en Actas del V Congreso Nacional sobre Problemáticas Sociales Contemporáneas (Santa $\mathrm{Fe}$, Facultad de Humanidades y Ciencias de la Universidad Nacional del Litoral, 2008). podemos citar casos tan diversos como emblemáticos. Entre ellos, Diálogo de exiliados/ Dialogue d'exilés (Raúl Ruiz, 1974) - trabajo ficcional con una fuerte base documental—, Acta General de Chile (Miguel Littin, 1986), Diario inconcluso/J ournal inachevé, Marilú Mallet, 1982), y los cortometrajes No olvidar (Ignacio Agüero, 1982) y Por la vida (Pedro Chaskel, 1987), por mencionar solo algunos variados ejemplos.

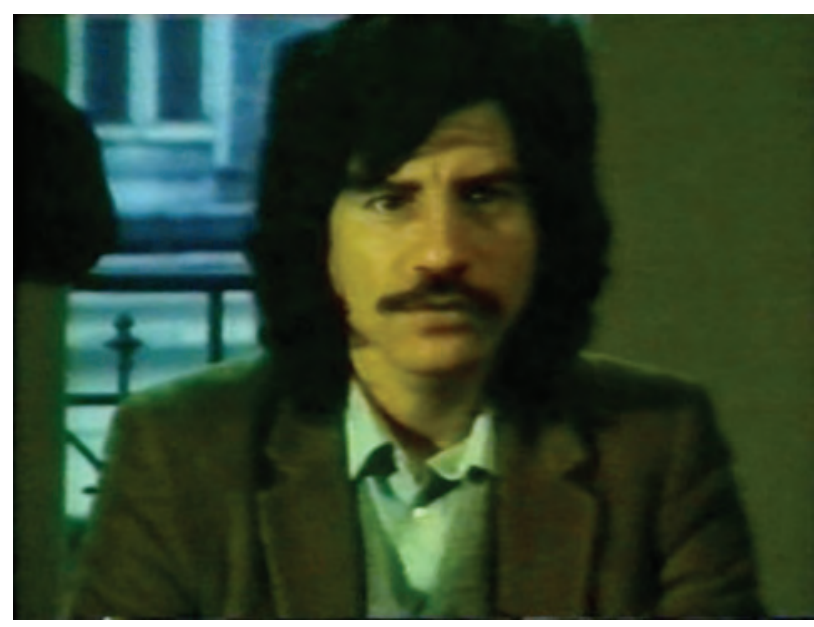

Diálogo de exiliados / Dialogue d'exilés (Raúl Ruiz, 1974).

\section{El posicionamiento de la Iglesia católica}

\subsection{La Iglesia argentina}

Un primer acercamiento a la puesta en escena de Todo es ausencia y En nombre de Dios, destaca, precisamente, por aquella discrepancia fundamental que motivó el proyecto fílmico de Guzmán: el deseo de exponer las posiciones diferenciadas que asumió la Iglesia católica frente a los regímenes dictatoriales en Chile y Argentina. Ese manifiesto apoyo que brindó la Iglesia argentina a la dictadura —entusiasmada por restaurar los principios de la "nación católica" ${ }^{14}-$, toma carnadura en el film de Kuhn a través de la experiencia de personas concretas. Tanto Todo es ausencia como En nombre de Dios se apoyan en los testimonios de las víctimas para reconstruir su relato, evidenciando el modo en que el acto de testimoniar se ha convertido en la modalidad decisiva de nuestra relación con los eventos de nuestros tiempos ${ }^{15} ; \mathrm{y}$, en particular, en la elaboración de la memoria del daño ${ }^{16}$. Tal como explica Gustavo Aprea, el testimonio se sostiene en una interacción escenificada, ya que se constituye como tal únicamente si participa de alguna manera de la esfera pública ${ }^{17}$. En estos casos, la presencia del testimoniante ${ }^{18}$ resalta la ausencia de esos otros que ya no podrán estar presentes para manifestar su 
propia experiencia ${ }^{19}$. Este factor se corrobora especialmente en el documental de Kuhn, donde los testimonios corresponden casi siempre a familiares de desaparecidos. Hacia el comienzo del film, las declaraciones de Marta Francese de Bettini —y de su hija Marta Bettini de Devoto—, ambas exiliadas en Madrid desde 1977, aluden a la desaparición forzada de varios miembros de su familia: el esposo de la primera, su hijo, su yerno y su madre. Una voice over presenta a Francese de Bettini, y, luego, al aludir a los parientes desaparecidos, la cámara focaliza en los retratos familiares de cada uno ellos, ubicados en su sala de estar. Dichas imágenes pertenecen a su ámbito privado, y es precisamente en dicho sitio donde el intercambio tendrá lugar. El film organiza su relato siguiendo este mismo esquema, esto es, articulando esfera pública y privada a través de las denuncias, la lucha y la resistencia promovidas por los familiares —principalmente, las Madres y Abuelas-de las víctimas del terrorismo de Estado.

A diferencia de otros testimonios que aparecen en Todo es ausencia, Francese de Bettinino se refiere a la militancia activa de ninguno de los miembros de su familia. Esta perspectiva entra en sintonía con la tendencia -que tenderá a imponerse en Argentina fundamentalmente después de la edición del Nunca más ${ }^{20}$ - a organizar una memoria colectiva sostenida a partir de la noción de «víctima inocente» ${ }^{21}$, en un país en el que las desapariciones objetivaron una decisión de exterminio político ${ }^{22}$. Según informa el documental, el marido de Francese de Bettini era fiscal y profesor universitario en la Facultad de Derecho, mientras que su yerno era teniente de fragata de la Marina de Guerra Argentina y habría desaparecido precisamente en el edificio Libertad - sede del Comando de la Marina de Guerra Argentina-mientras intentaba dar noticia a las autoridades de su fuerza sobre la desaparición y asesinato de su cuñado y suegro. Francese de Bettini atribuye el asesinato de su hijo - el primer secuestrado de su familia- a su fe cristiana, puesto que él habría «entendido el verdadero evangelio» y la importancia de ayudar a los que menos tienen. Tanto los gestos como los modismos en el habla de madre e hija evidencian su condición de clase acaudalada, lo cual es confirmado por los vínculos y relaciones que les habrían permitido, «como una concesión muy especial», la devolución del cadáver de su hijo y hermano respectivamente, enterrado en una fosa común junto con otros muchos jóvenes no identificados. Mientras el audio del testimonio de la madre hace referencia a la entrega de su hijo a la causa de los pobres, vemos en pantalla imágenes deasentamientos, viviendas precarias donde viven en Argentina los más humildes, las cuales aluden al objeto de las acciones de su hijo, pero también evidencian la diferencia de clase entre estos grupos sociales.

Las gestiones de estas mujeres en busca de sus seres queridos las condujeron hasta el Vaticano. Según la narración de la madre, es precisamente en la santa sede donde comprobaron la complicidad entre el episcopado argentino y la institución militar, dado
[19] Bhaskar Sarkar y Janet Walker, «Introduction. Moving Testimonies», en Bhaskar Sarkar y Janet Walker (eds.), Documentary Testimonies. Global Archives of Suffering (Nueva York y Oxon, Routledge, 2010), p. 6.

[20] Marina Franco, «"La teoría de los dos demonios" en la primera etapa de la posdictadura», en Claudia Feld y Marina Franco (dirs.), Democracia, hora cero: actores, políticas y debates en los inicios de la posdictadura (Buenos Aires, Fondo de Cultura Económica, 2015), pp. 23-80.

[21] Pilar Calveiro, Política y/o violencia. Una aproximación a la guerrilla de los años 70 (Buenos Aires, Grupo Editorial Norma, 2005).

[22] Emilio Crenzel, La historia política del Nunca más. La memoria de las desapariciones en la Argentina, p. 27.

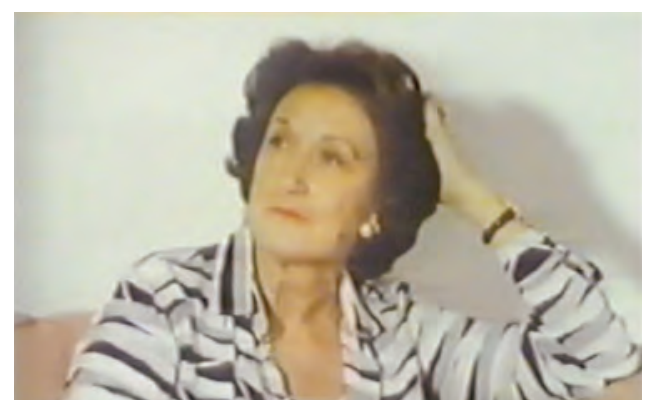

Todo es ausencia (Rodolfo Kuhn, 1984). 
[23] Marta Francese de Bettini hace referencia al cardenal Primatesta, el arzobispo Derisi y el nuncio Pio Laghi -amigos y conocidos de su familia-, quienes, pudiendo haberlas ayudado, se negaron a recibirlas y/o a brindarles auxilio.

[24] En su testimonio, Hebe de Bonafini reivindica las figuras de Jaime de Nevares, Rubén Capitanio y Miguel Hesayne como esa parte de la Iglesia que se habría mostrado solidaria y que estaría «del lado del que necesita realmente».

[25] En Argentina, distintos documentales han retratado el vínculo de los sacerdotes tercermundistas con la causa del pue blo o la labor de figuras como los Obispos Enrique Angelelli y Jaime de Nevares - entre ellos Angelelli, con un oído en el pueblo y otro en el evangelio (Mario Bomheker, 1986), Entre el cielo y la tierra (J orge Denti, 1986) y Jaime de Nevares, último viaje (Marcelo Céspedes y Carmen Guarini, 1995)_. Estos films evidencian el compromiso social de estos clérigos, diferenciándolos, al mismo tiempo, del rol cómplice que habría asumido la cúpula eclesiástica durante los tiempos de represión.

[26] María Soledad Catoggio, Los desaparecidos de la iglesia. $\mathrm{El}$ credo contestatario frente a la dictadura (Buenos Aires, Siglo Veintiuno Editores, 2016), p. 150 .

[27] La Razón, 15/09/76, citado por Eduardo Blaustein y Martín Zubieta, Decíamos ayer. La prensa argentina bajo el Proceso (Buenos Aires, Colihue, 1998), p. 154.

[28] María Soledad Catoggio, Los desaparecidos de la iglesia. $\mathrm{El}$ credo contestatario frente a la dictadura, p. 247. que, según les informaron allí, «el episcopado argentino es el más conservador del mundo». En Roma, cardenales amigos de su familia se negaron a recibirlas o prestarles ayuda ${ }^{23}$. Siguiendo su testimonio —reforzado luego por la palabra de miembros de Abuelas y Madres de Plaza de Mayo—, la Iglesia argentina no solo habría estado al tanto de la violencia ejercida por el Estado, sino que distintos sacerdotes se habrían hecho presentes en los campos de concentración y habrían presenciado, incluso, la tortura. Otros testimonios que integran el film, al tiempo que reiteran esta misma denuncia, contribuyen a matizar de algún modo la acusación, aclarando que también existiría la «otra iglesia», «la del pueblo» 24 , aquella fracción minoritaria que se solidarizó con la lucha popu$\operatorname{lar}^{25}$. Estas características de los testimonios tienden a destacar la tesis, popularizada durante los años de transición, que postula la existencia de «dos iglesias: una cómplice y otra perseguida» ${ }^{26}$. En dicho imaginario, la postura de la Iglesia cómplice se sostenía a partir de la reivindicación del rol de las Fuerzas Armadas, la condena de la acción de «los grupos marxistas» y el desentendimiento respecto de las violaciones a los derechos humanos. Las declaraciones de Monseñor Tortolo, recuperadas y publicadas en el diario La Razón en 1976, ilustran, de algún modo, esta posición:

«Las estadísticas señalan que la mayor parte de los guerrilleros son hijos de hogares rotos o mal avenidos, otros fracasaron en sus estudios universitarios o tuvieron diversos problemas, sin excluir que subyace, en el fondo, un afán de aventuras». Respecto de presuntas violaciones de los derechos humanos en la Argentina, afirmó categóricamente: «No tengo un argumento ni pruebas fehacientes para decir que sí. Lo oigo, lo escucho, hay voces, pero la realidad es la siguiente: a mí no me consta y el mal tengo que probarlo, no basta con suponerlo»²7.

Por fuera de esta perspectiva polarizada entre las dos iglesias, fueron muchos los miembros de dicha institución que sufrieron actos de violencia. María Soledad Catoggio explica que las narrativas de memoria de la postdictadura tendieron a subsumir a las víctimas de dichas violaciones de los derechos humanos como parte del tercermundismo, cuando, en realidad, gran parte de ellas se concentró también en las filas del clero regular ${ }^{28}$. Según sostiene el fraile Antonio Puigjané —discípulo del Obispo Enrique Angelelli, asesinado en condiciones no esclarecidas-, «en la Iglesia, hubo mucha gente que se juzgó y fue torturada y desaparecida y hasta asesinada [...]. Si como Iglesia hubiésemos enfrentado al RÉGIMEN criminal, se [habrían] evitado MILES DE MUERTES» ${ }^{29}$. Si, por una parte, los testimonios que recupera el film evidencian la complicidad entre la cúpula eclesiástica argentina y el gobierno dictatorial, por otra, estas experiencias también demuestran el modo en que, lejos de restringirse a un sector político o social en particular, el terrorismo de Estado actuó sobre el entramado social en su totalidad. 


\subsection{La Iglesia chilena}

Ya hacia el inicio de En nombre de Dios, las diferencias entre los roles de la Iglesia chilena y argentina se tornan más que evidentes. Si en Todo es ausencia casi no hay testimonios de miembros de la Iglesia argentina y son los familiares de las víctimas del terrorismo de Estado las que denuncian la connivencia entre dicha institución y la dictadura, el documental de Guzmán se nutre en gran medida, por el contrario, de testimonios de párrocos de distintos sectores y jerarquías que dan cuenta de su oposición al régimen de Augusto Pinochet y su solidaridad con las víctimas. Pero, más allá del apoyo de la Iglesia a la causa popular, el documental de Guzmán también alude a aquel sector del episcopado que sí mantuvo relaciones de cercanía con el poder dictatorial. Estos sectores son identificados con rituales celebrados en majestuosas catedrales y se condensan, principalmente, en la ceremonia de bendición de armas.

Hacia el comienzo de En nombre de Dios, se entabla un recorrido por la Vicaría de la Solidaridad, creada en 1976 con el objeto de asistir a las víctimas de la dictadura militar, brindarles asesoramiento jurídico, defensa legal y atención médica. La cámara sigue a Gustavo Villalobos, abogado de la Vicaría, por los pasillos de la institución, reproduciendo un itinerario similar al que realizaría una persona en busca de ayuda y, por lo mismo, identificándose con dicho rol. Como parte del recorrido, se incluyen declaraciones de distintos colaboradores de dicha entidad, pero, a su vez, el micrófono de Guzmán va entrevistando a aquellas personas que cruza a su paso, las cuales se acercaron a la Vicaría en busca de ayuda. El film también registra una reunión de familiares de desaparecidos llevada a cabo en dicha institución. La cámara sigue la ronda de experiencias que comparten los asistentes,

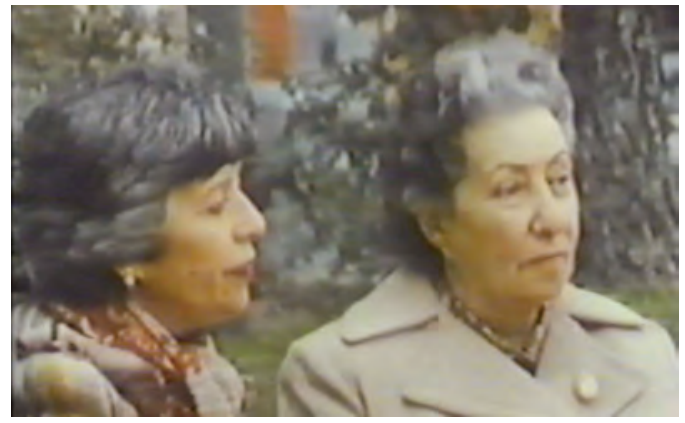

En nombre de Dios (Patricio Guzmán, 1987). en su mayoría mujeres - algunas de ellas de edad avanzada - intercambiando variadas tácticas de resistencia —entre ellas, la aplicación de cremas debajo de los ojos, la aspiración de vinagre y sal o colonia-con el objeto de contrarrestar los efectos de la represión policial en las manifestaciones de protesta en la vía pública. Estos relatos son intercalados con imágenes callejeras en las que puede apreciarse cómo los gases arrojados por la policía y los camiones hidrantes reprimen con igual intensidad a mujeres mayores y a gente con discapacidades que son trasladados en sillas de ruedas.

Uno de los pasajes que mejor condensan la estrecha relación entre la Iglesia chilena y las víctimas del terrorismo de Estado corresponde a una procesión de via crucis que adquiere, en dicho contexto de dictadura, las características de una manifestación política, seguida y vigilada por la policía. En un comienzo -mientras se escuchan cánticos religiosos de fondo—, la cámara se cierra 
sobre un pequeño grupo de párrocos que discuten con discreción la exigencia del capitán de carabineros de retirar toda leyenda política de las pancartas y carteles que llevan los feligreses. Ante tal demanda, los sacerdotes acceden a conservar solamente las consignas religiosas, acordando entre ellos que los lemas religiosos y políticos muchas veces coinciden. La cámara, ubicada por momentos desde dentro de la procesión, evidencia la posición de los creyentes manifestantes ${ }^{30}$, mostrando cómo la columna

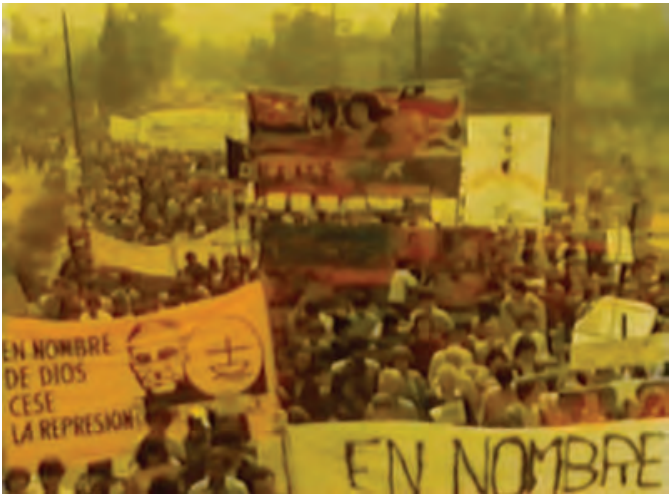

Todo es ausencia. de feligreses avanza por el centro de la calle, coreando no un cántico religioso tradicional, sino la consigna «justicia, justicia, queremos justicia». Los carteles que portan muchos de los participantes permiten leer frases como «Caín ¿dónde está tu hermano? Asociación de Familiares de Desaparecidos». Otras pancartas llevan fotos de desaparecidos con la leyenda «exigimos justicia» o la pregunta «¿dónde están?». Una de las pancartas más llamativas permite leer «En nombre de dios que cese la represión», frase que entabla un diálogo con el título del film de Guzmán. Por un breve momento, la cámara abandona la procesión para detenerse en las acciones de un joven que escribe con aerosol en un muro «La esperanza cristiana es socialista». Los planos generales de este acto religioso —que son precisamente retomados hacia el final, para dar cierre al film- permiten ver cómo las cruces sostenidas en alto por los manifestantes se alternan y fusionan con los carteles y pancartas de denuncia. Ubicadas hacia el final del documental, estas imágenes resultan conclusivas porque exponen nítidamente la íntima vinculación entre la creencia religiosa y la convicción política, el modo en que la movilización cristiana y la resistencia a la dictadura confluyen. Por otra parte, estos pasajes también nos hablan de ciertas características del pueblo

[30] El punto de vista cambia cuando la cámara se acerca a los carabineros que vigilan el recorrido de los feligreses para preguntarles si todo está en orden. Dichos pasajes, que exhiben el doble discurso de los militares -dado que estos ocultan la orden de quitar las consignas religiosas de los carteles-, coinciden también con un desplazamiento del dispositivo de captación de imágenes hacia fuera de la columna delos manifestantes. La entrevista, en estos breves momentos, se traslada del registro de las víctimas para denunciar a los victimarios, a través de herramientas provenientes del campo periodístico. chileno, específicamente, el modo en que la religión atraviesa un sinfín de prácticas culturales, entre ellas, la educación y la mirada política. En este caso puntual, una práctica tradicional —como la religiosa—, se mezcla con una fuerza de ruptura tal que vuelve posible la desobediencia al régimen militar.

\section{La resistencia}

\subsection{Madres y Abuelas de Plaza de Mayo}

La resistencia a la dictadura en el film de Kuhn está encarnada, fundamentalmente, por la lucha promovida por Madres y Abuelas de Plaza de Mayo. Las movilizaciones de Madres y Abuelas de Plaza de Mayo nacieron durante los años de represión, con el objeto de denunciar y dar con el paradero de sus hijos desaparecidos — en el caso de las primeras-y de sus nietos secuestrados 
y/ o nacidos en cautiverio - en el caso de las segundas-. Hacia el desmoronamiento de la dictadura, se sumarían las reivindicaciones de juicio y castigo a los culpables de crímenes de lesa humanidad y se emplearían nuevas estrategias creativas para visibilizar a los desaparecidos y a las víctimas del terrorismo de Estado ${ }^{31}$. En el momento bisagra en el que se ubica Todo es ausencia, hacia el final del régimen militar y el retorno republicano, las acciones de intervención que promueven estos organismos de derechos humanos permiten, precisamente, destacar continuidades entre dictadura y democracia a través de su lucha.

En Argentina, las mujeres tuvieron un gran protagonismo en acciones de manifestación pública en contra de la dictadura. Las movilizaciones semanales de Madres de Plaza de Mayo tuvieron como motor estratégico, precisamente, su condición de género, puesto que la presencia de hombres en dichos actos hubiese desencadenado las más crudas represalias. Así, estas marchas circulares rodeando la pirámide de Mayo, son una de las pocas formas de manifestación contra la dictadura que tuvieron lugar en la vía pública argentina durante los años del régimen militar, dado que, en aquel entonces, la crudeza de la violencia tornaba inviable cualquier otro modo de protesta. En términos generales, la gran mayoría de las imágenes correspondientes a las marchas y denuncias de las Madres de Plaza de Mayo que han circulado durante la dictadura fueron tomadas por la corresponsalía extranjera — principalmente por la televisión francesa, alemana y española-, siendo luego recuperadas, en la mayor parte de los casos, como material de archivo por el documental cinematográfico «del retorno» ${ }^{32}$. Por esa razón, aparte de la petición desesperada de ayuda de las Madres de Plaza de Mayo - y de otros pocos eventos puntuales, como la Plaza en contra de la Guerra de Malvinas, la «Marcha por la Vida» y otra serie de manifestaciones públicas en favor de los derechos humanos y la democracia que ya se inscriben en la serie del retorno democrático- no hay casi, en los films documentales que abordan la dictadura, imágenes de manifestaciones de protesta que desafíen al régimen durante los años más crudos de represión, puesto que la acción del terrorismo de Estado en Argentina se desarrolló en la clandestinidad —aun cuando los secuestros se realizaban muchas veces a los ojos de todos, en la vía pública-. Tal como explica Emilio Crenzel, la clandestinidad es una de las particularidades que distinguió a la dictadura argentina respecto de las modalidades represivas que se establecieron en el Cono Sur de América Latina ${ }^{33}$. Estos factores han influido en que, en la generalidad de los documentales, al aludir al período 1976-1983, se apele genéricamente a imágenes de archivo de momentos anteriores ${ }^{34}$, puesto que prácticamente no han circulado imágenes de la represión durante el período 1976-1983.

El documental de Kuhn se nutre, en gran medida, de materiales de registro que capturan en tiempo presente las acciones de Madres y Abuelas de Plaza de Mayo. Al igual que en el trabajo de Guzmán, los testimonios ocupan un lugar protagónico en el film, cobrando relevancia el gesto, la mirada y el rostro. Tal como nota Gonzalo Aguilar, el cine documental latinoamericano
[31] Ana Longoni, et al, «Introducción. Perder la forma humana. Una imagen sísmica de los años ochenta», en Perder la forma humana. Una imagen sísmica de los años ochenta en América Latina (Madrid, Museo Nacional Centro de Arte Reina Sofía, 2014).

[32] Se trata de materiales obtenidos de la cobertura del mundial de fútbol y de la visita de la Comisión de Derechos Humanos de la OEA en los años 1978 y 1979, respectivamente.

[33] Emilio Crenzel, La historia política del Nunca más. La memoria de las desapariciones en la Argentina, p. 27.

[34] Lior Zylberman, Estrategias narrativas de un cine postdictatorial. El genocidio en la producción cinematográfica argentina (1984-2007), Tesis de Maestría en Comunicación y Cultura (Facultad de Ciencias Sociales, Universidad de Buenos Aires, 2011). 
[35] Gonzalo Aguilar, Más allá del pueblo. Imágenes, indicios y políticas del cine (Buenos Aires, Fondo de Cultura Económica, 2015). Si bien esta conceptualización de Gonzalo Aguilar se refiere principalmente al cine de memoria, consideramos que algunas de sus observaciones también iluminan una parte del cine latinoamericano realizado desde el exilio.

[36] Elizabeth Jelin, Los trabajos de la memoria (Buenos Aires, Siglo XXI, 2002).

[37] Estas declaraciones de Bonafini corresponden a su participación testimonial en Todo es ausencia.

[38] Este tramo del film está acompañado por el tema musical Si yo supiera tu nombre, en la voz de Ana Belén. que trata sobre la dictadura y el pasado reciente se muestra obsesionado por la «rostrificación» de la imagen, en la que intenta cifrar una historia, una memoria, un espacio y una subjetividad ${ }^{35}$. Tal como planteamos más arriba, Todo es ausencia tiene el mérito de ser uno de los primeros documentales en abordar el tema del terrorismo de Estado en Argentina. Por ese motivo, los testimonios que incluye -más allá de su evidente convencionalismo formal-implican una gran ruptura al tornar audibles esas voces que habían sido acalladas durante los años de represión. En estos casos, el dispositivo testimonial funciona como articulador de la mirada colectiva e individual, capaz de expresar las tensiones entre lo decible y lo no decible ${ }^{36}$.

Parte del valor de los testimonios que aparecen en Todo es ausencia remite a su cercanía en el tiempo con los hechos a los que aluden, desvelando ciertas tramas de la actuación de los militares que, por aquel momento, no resultaban del todo conocidas tanto dentro como fuera de la Argentina. La cercanía respecto de los hechos se advierte en la sensibilidad que emerge en varios de los testimonios, el dolor a flor de piel que apenas comenzaba a ser procesado por los familiares de las víctimas. Este factor se torna especialmente evidente en las declaraciones de Hebe de Bonafini, una de las fundadoras de Madres de Plaza de Mayo y directora de dicha entidad, quien se quiebra a la hora de referirse al secuestro y desaparición de sus hijos. Esta visión de una Bonafini acongojada contrasta notablemente con la imagen de mujer fuerte — capaz de «transforma[r] el dolor en lucha» ${ }^{37}$ que la caracteriza como personaje público.

Por su parte, el metraje de archivo histórico, cuando aparece, remite al pasado reciente, aludiendo, generalmente, a las acciones o discursos públicos de la junta militar. En el marco del film, estos materiales de archivo suelen utilizarse en forma ilustrativa o, más frecuentemente, como contrapunto de los testimonios. Así, mediante el contraste - como si fuera un careo-, se exaltan las diferencias entre los dichos de los uniformados y las experiencias traumáticas de los familiares de desaparecidos, con los que se identifica el documental. El film también se nutre de materiales de archivo provenientes del universo privado de los testimoniantes. Estas filmaciones caseras y fotografías familiares, que emergen desde su esfera íntima, se tornan políticas a partir de su relevancia pública, nutriendo de singularidad y subjetividad las denuncias.

En el plano de las imágenes, la lucha de Madres y Abuelas de Plaza de Mayo toma forma a través de dos tipos de movilizaciones: a) en primer lugar, las marchas e intervenciones en el espacio público argentino; y b) los viajes y desplazamientos internacionales que emprenden en búsqueda de apoyo.

a) Posiblemente uno de los momentos más potentes del film -aquel que coincide en el plano sonoro con el leit motiv «Todo es ausencia» en la voz de Ana Belén- ${ }^{38}$ refleja, precisamente, la tenacidad, fuerza y persistencia que caracteriza la lucha de las Madres de Plaza de Mayo a través de sus marchas y acciones colectivas. Por medio de un plano aéreo, vemos a distancia la característica marcha circular rodeando la pirámide de la Plaza de Mayo. A medida 
que la panorámica cede lugar a un plano general, observamos desde más cerca la caminata lenta pero constante bajo los paraguas. Los primeros planos permiten ver la diversidad de rostros, en su mayoría mujeres, algunas de edad avanzada, aunados por los pañuelos blancos bajo la lluvia. Varias portan las fotos de sus familiares desaparecidos. Por momentos, la cámara focaliza en sus pies, en las sandalias y tacones altos que atraviesan charcos en esa marcha reiterada. Luego, las vemos dirigirse hacia el Congreso de la Nación por el centro de la calle. En las imágenes que ofrece este pasaje del film, la concentración de individuos, si bien resulta significativa - sobre todo si se lo compara con las primeras movilizaciones, allá por el año 1977—, no llega, sin embargo, a ser multitudinaria. Según deja apreciar el documental, la columna se mueve formando un bloque compuesto por personas abrazadas por la cintura o tomadas del brazo bajo los paraguas, corroborando la idea de que el roce de los cuerpos en las marchas
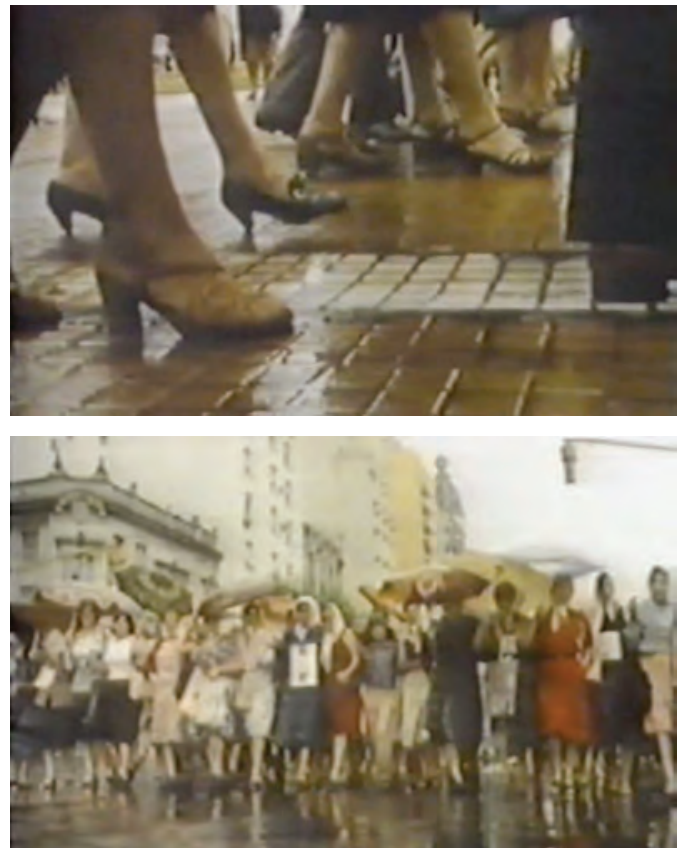

Todo es ausencia. ayudaría a reconstruir lazos afectivos quebrados por el terror ${ }^{39}$.

Antes de la aparición del Nunca más y del juicio a las juntas militares -dos momentos claves en el proceso de construcción de ciertos sentidos sobre el pasado argentino ${ }^{40}$, que tendrían una función reveladora, evidenciando lo que hasta entonces había sido secreto, ya que la mentira y el encubrimiento en el ámbito público habían completado la modalidad represiva de la desaparición ${ }^{41}$, las Madres no habían despertado aún el apoyo social que llegarían a tener con el paso del tiempo, al alcanzarse un conocimiento más acabado sobre los tormentos vividos durante la dictadura y al establecerse cierto consenso social respecto de cómo pensar y condenar la violencia. Incluso, hacia el rodaje del film, es probable que las Madres fuesen aún víctimas de la estigmatización social ${ }^{42}$. Este pasaje del documental de Kuhn captura precisamente este momento con gran pericia: aquel en el que estos muchos — que seguían aunando fuerzas y juntando voluntades para hacer público su reclamo- eran dejados en soledad. En ese sentido, el documental evidencia cómo el cambio de signo político —el pasaje de dictadura a democracia o, en su defecto, esa zona de transición entre ambasno implica necesariamente una modificación automática en el lugar social que ocupan determinados agentes, como en este caso, las agrupaciones en defensa de los derechos humanos. El film refuerza a nivel visual el mismo concepto que sostiene a través de los testimonios, esto es, el de dar visibilidad a las víctimas que buscan hacer audible su denuncia frente a distintas instituciones queles dieron la espalda, evidenciando el poder de su ausencia —en particular, del Estado

[39] Ana Longoni, et al, «Introducción. Perder la forma humana. Una imagen sísmica de los años ochenta», p. 14.

[40] Claudia Feld y Marina Franco, «Introducción», p. 11.

[41] Claudia Feld, Del estrado a la pantalla. Las imágenes del juicio a los ex comandantes en Argentina (Madrid, Siglo Veintiuno Editores, 2002); Claudia Feld, " "Aquellos ojos que contemplaron el límite": la puesta en escena televisiva de testimonios sobre la desaparición», en Claudia Feld, yJ essica Stites Mor (comps.), El pasado que miramos. Memoria e imagen ante la historia reciente (Buenos Aires, Paidós, 2009), pp. 77-109.

[42] Durante sus primeros años de lucha, era común que la gente se dirigiera a ellas como «las locas de Plaza de Mayo». 
en tiempos de dictadura, los medios de comunicación y la Iglesia católica一 - La lluvia refuerza la carga dramática de la vivencia del dolor y de la tenacidad colectiva, mostrando cómo este grupo logra marchar pese a todo.

b) En segundo lugar están los desplazamientos en el espacio, las gestiones y los viajes que las Abuelas y Madres de Plaza de Mayo emprenden con la finalidad de difundir mundialmente los horrores vivi-
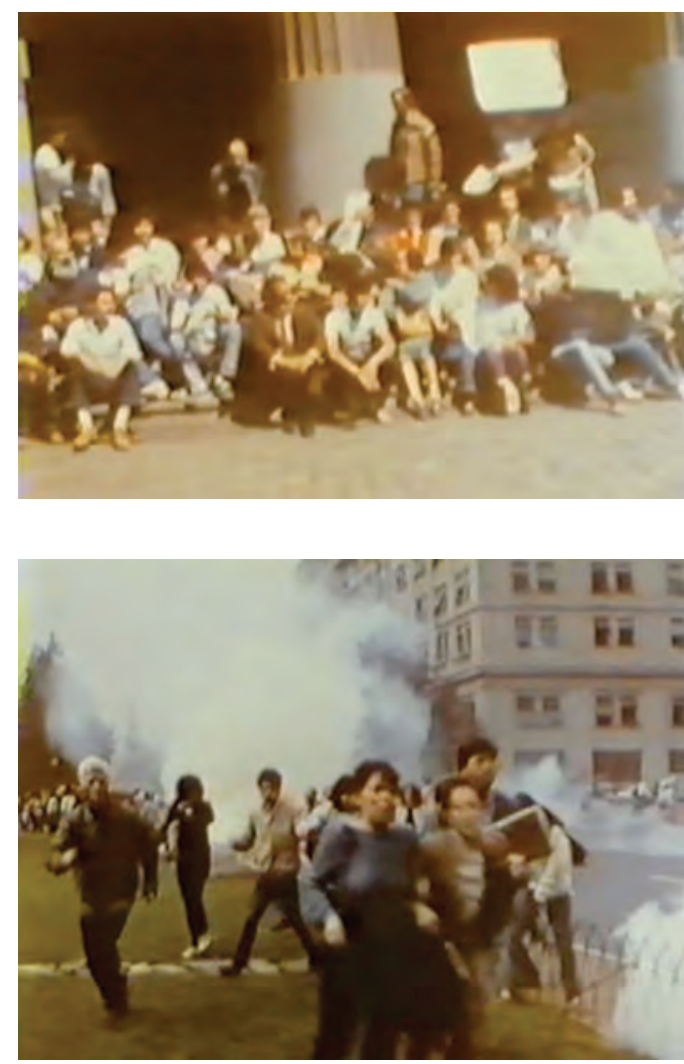

Todo es ausencia. dos en la Argentina, dar a conocer su lucha, buscar avales y ayuda. De ese modo, vemos el arribo de Hebe de Bonafini a España. La planificación del documental sigue parte de su agenda, la cual involucra entrevistas televisivas y una charla ante un público de mujeres en la sede del Partido Socialista Obrero Español. Al igual que con las actividades de las Abuelas y Madres de Plaza de Mayo, la cámara acompaña sus gestiones y actividades, informándose de su lucha al tiempo que comparte el rol del público asistente en estas reuniones.

Todo es ausencia también acompaña en su recorrido por Madrid a Antonia Acuña de Segarra y a María Alexiu de Ignace, dos Abuelas de Plaza de Mayo que difunden su búsqueda a través de distintas acciones. La cámara las escolta al Centro Guadalupe, institución educativa donde participan de una actividad en la clase de dibujo. Las preguntas que los niños dirigen a las Abuelas -quienes buscan a unos nietos que en muchos casos no tuvieron la oportunidad de conocer, puesto que sus hijas o nueras dieron a luz en centros clandestinos- tienden de algún modo a desnaturalizar los hechos, generando extrañeza frente a la crueldad de una situación que se interpone en el fluir de los lazos afectivos con sus descendientes biológicos. La exhibición de los dibujos, realizados por los estudiantes como fruto del intercambio, muestra un tipo de expresividad que excede la palabra - predominante en los testimonios de los adultos-, aportando la mirada del mundo infantil, compatible, en potencia, con la perspectiva de sus nietos ausentes.

\subsection{La resistencia chilena en las calles}

La lucha de las mujeres contra la dictadura también tuvo un rol fundamental en Chile. Fueron varios los grupos que se movilizaron políticamente, entre ellos, Agrupación de Familiares de Detenidos Desaparecidos, Agrupación 
de Familiares de Presos Políticos, Mujeres por la Vida, etc. Estos colectivos estaban integrados fundamentalmente por madres y esposas, puesto que la gran mayoría de desaparecidos eran hombres ${ }^{43}$. A través de distintas acciones, marchas e intervenciones, estas mujeres lograron darle visibilidad pública a la experiencia de violación de los derechos humanos en Chile.

En nombre de Dios recupera algunas acciones de Mujeres por la vida, colectivo que, como explicita Temma Kaplan, consideró la desobediencia civil como una forma de crear la democracia, buscando

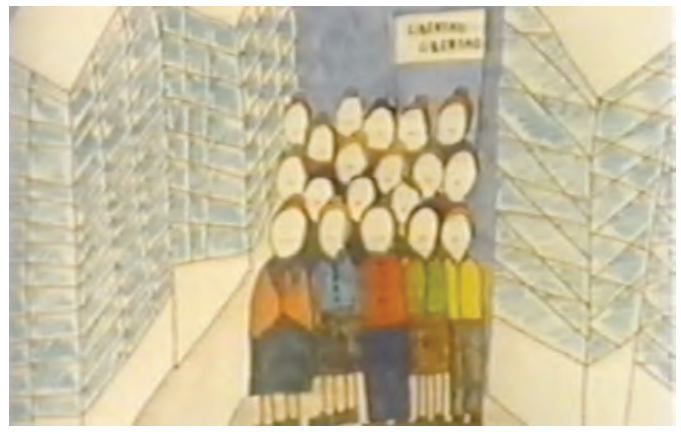

Todo es ausencia. ayudar a las mujeres a sobrellevar el miedo a oponerse a la policía y a enfrentar el tema de la violencia de género ${ }^{44}$. Según explican Fernanda Carvajal y J aime Vindel, este amplio grupo habría logrado reinstalar en tiempos de dictadura ciertas tensiones en relación a lo público y lo privado - el «desplazamiento de la casa a la calle» ${ }^{45}$ - , que ya habían sido materializadas con la irrupción de la mujer de derechas en la vía pública hacia los años setenta. Esta situación inicial se originó como una forma de manifestar la oposición al gobierno de Salvador Allende, promoviendo las «protestas de las madres», las cuales colmaron la ciudad de Santiago con ruidos de cacerolas -como puede verse en La batalla de Chile ${ }^{46}$ — . Las acciones de Mujeres por la Vida, entonces, tenían por cometido torcer el signo político conservador de aquella irrupción anterior en la arena pública, reemplazando la categoría de «madre» por la de «mujer». De acuerdo con estos principios, el grupo se había propuesto «...destacar la afirmación de la vida, el reconocimiento de la mujer como agente político, la rebeldía contra la dictadura manifestada en la presencia pública de los cuerpos disidentes y el reclamo de retorno de la democracia como cambio político que asegurara la vigencia de los derechos humanos» ${ }^{47}$. En nombre de Dios también recupera la resistencia de las mujeres a la dictadura a través del arte de denuncia en arpilleras. El film repone, a través de testimonios, la motivación de esta lucha, siguiendo mediante imágenes parte de los emprendimientos vinculados a este tipo de expresión. Otras formas comunitarias, como La olla común, también son presentadas en el documental como parte de iniciativas generadas desde los sectores populares en las que las mujeres juegan un papel decisivo.

En el plano visual, En nombre de Dios presenta la resistencia a la dictadura a través de dos recursos predominantes: a) las prácticas de resistencia en las calles —organizadas mayormente por Mujeres por la Vida, a las que se suman las acciones contra la tortura lideradas por el teólogo J osé Aldunate-, seguidas luego por la represión militar; y b) el testimonio de sacerdotes de diversas jerarquías que explicitan sus críticas al régimen de Pinochet, describiendo también distintas tácticas y estrategias por ellos promovidas.

a) En nombre de Dios searticula, en gran medida, a partir de una dialéctica que intercala testimonios e imágenes de la resistencia en la vía pública con ac-

[43] Sonia Montecino, «Dimensiones simbólicas del accionar político y colectivo de las mujeres en Chile. Una propuesta de lectura desde la construcción simbólica del género», en L. Luna y M. Vilanova Sims, Desde las orillas de la política. Género y poder en América Latina (Barcelona, Universidad de Barcelona, 1996), pp. 101-116.

[44] Temma Kaplan, Taking Back the Streets. Women, Youth, and Direct Democracy (Berkeley, Los Angeles y Londres, University of California Press, 2004), pp. 83-86.

[45] Sonia Montecino, «Dimensiones simbólicas del accionar político y colectivo de las mujeres en Chile. Una propuesta de lectura desde la construcción simbólica del género», p. 105.

[46] Fernanda Carvajal y Jaime Vindel, «Acción relámpago», en Perder la forma humana. Una imagen sísmica de los años ochenta en América Latina (Madrid, Museo Nacional Centro de Arte Reina Sofía, 2014), p. 39.

[47] Fernanda Carvajal y Jaime Vindel, «Acción relámpago», p. 39. 
ciones represivas en las que se arrojan gases, intervienen camiones hidrantes y los uniformados sellevan, generalmente, a algunos detenidos - entre ellos, dos integrantes del grupo de filmación-. Esta lógica de protesta-represión, que involucra muchas veces la explicitación de tácticas y estrategias dispuestas para la lucha, tiende a enfatizar la forma en que se construye el «poder popular» ${ }^{48}$, aspecto que resulta recurrente en buena parte de la filmografía de Guzmán.

El film arranca con imágenes de la Jornada por el derecho a la democracia convocada por Mujeres por la vida en marzo de 1986. Mientras se escucha de fondo a los manifestantes corear «Vamos Chile,

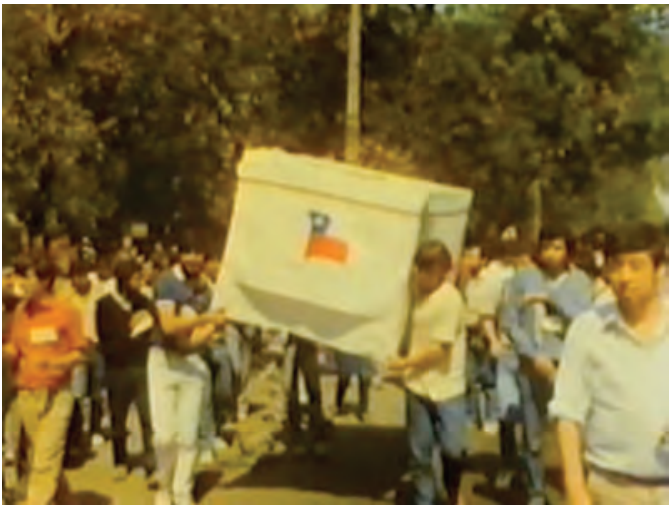

En nombre de Dios. caramba. Chile no se rinde, caramba», asistimos al corte de una calle en la ciudad de Santiago. La cámara se desplaza a lo ancho de la avenida, siguiendo las acciones de los militantes que aplauden y corean de pie, o acostados en el asfalto por donde deberían circular los automóviles, que esperan detenidos a pocos metros. A continuación, la lente focaliza en una gran urna instalada en la vía pública, la cual lleva la leyenda «Yo voto $\mathrm{x}$ democracia». Las siguientes imágenes muestran cómo se introducen en ella votos que, según se explicitará con posterioridad, permitirían optar entre democracia y dictadura. Esta simulación de un plebiscito —bajo la consigna «votemos por democracia: botémoslo [a Augusto Pinochet]»—, habría tenido entre sus cometidos destacar precisamentela cuestión del voto en un país en el que los registros electorales estuvieron cerrados por quince años ${ }^{49}$.

La contracara de estas imágenes de resistencia en las calles corresponde a las maniobras represivas. Así, vemos cómo los uniformados irrumpen en la manifestación, llevándose detenidos a algunos participantes, tirándolos al suelo arrastrándolos de los pelos, etc. Con posterioridad, los camiones hidrantes intentarán hacer retroceder a los manifestantes, que se protegen con ramas de árboles o responden tirando piedras hacia los tanques militares. La cámara se mueve entre los gases lacrimógenos, siguiendo a los policías que corren protegidos con sus máscaras, y oscila en ocasiones compartiendo nuevamente el punto de vista del público movilizado.

Contrariamente a Todo es ausencia - y al cine documental argentino del período en general-, en el que casi no existen imágenes de la violencia tomadas durante la última dictadura militar, en el cine chileno abundan las cintas

[48] Jorge Ruffinelli, El cine de Patricio Guzmán. En busca de las imágenes verdaderas, p. 149.

[49] Fernanda Carvajal y Jaime Vindel, «Acción relámpago», p. 39. con materiales de registro sobre las manifestaciones contra la dictadura y la represión policial en las calles —como la que describimos más arriba- La precisión y minuciosidad de este metraje es tal, que en variados documentales del período, al aludir a través de testimonios o narraciones a distintos sucesos, existe casi siempre el apoyo de un caudal de archivo que permite remitirse pormenorizadamente a dichas situaciones puntuales, recuperando 
en el plano visual las vivencias descriptas a través de la palabra de los protagonistas. Más aún, la propia cinematografía de Guzmán conforma un archivo de la experiencia y una memoria de la resistencia antes, durante y con posterioridad al golpe de Estado en Chile ${ }^{50}$.

Un ejemplo de la utilización de este pormenorizado cúmulo de material de registro que irá conformando indirectamente un archivo sobre la protesta y represión en Chile es el testimonio del sacerdote Pierre Dubois que, según se aclara en el zócalo de la pantalla, sería posteriormente expulsado de dicho país. Tal como describe en su testi-

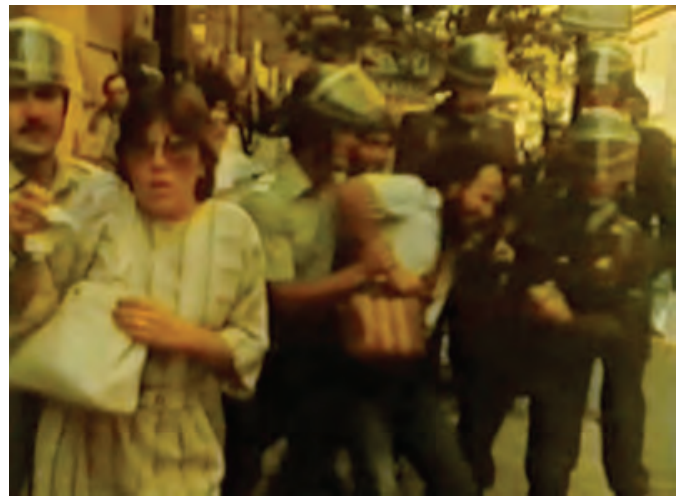

En nombre de Dios. monio, Dubois habría sido detenido en marzo de 1984 con la acusación de impedir acciones de carabineros, cuando intentaba evitar que los militares ingresasen en un barrio de viviendas humildes. Las declaraciones del párroco son intercaladas con material de registro que va ilustrando -y corroborando- su narración. Las imágenes lo muestran intentando conversar con los uniformados, quienes disparan en dirección hacia donde se encuentran las viviendas y también el propio párroco. Según describe el sacerdote, él habría tratado de explicar a los militares que, de entrar, la situación empeoraría, pero como ellos no entendían sus argumentos, habría decidido ponerse en el suelo, delante del bus de traslado para impedir su paso. El relato es complementado por inestables imágenes que muestran las persecuciones de los militares entre gases, intentando asestar a sus blancos que se mueven a lo lejos. Otras vistas presentan al contrariado sacerdote entre medias de los dos bandos: de un lado, los uniformados portando armas y escudos, y disparando gases; del otro, un poco más lejos, los vecinos. Luego de un corte de edición, vemos avanzar una columna de pobladores por el centro de la pantalla coreando «el pueblo unido, jamás será vencido» mientras levantan al cura en andas.

Es frecuente también, en estos casos, ver una o más cámaras de cine y/ o vídeo tomando imágenes del mismo suceso —como ocurre con las imágenes de la jornada en favor de la democracia promovida por Mujeres por la vida, pero también en los sucesos que involucran al sacerdote Pierre Dubois recién referidos-. Si bien esta multiplicidad de registros y de dispositivos de filmación obedece, en algunos casos, a la cobertura de los eventos por parte de la corresponsalía extranjera, en muchos otros, se explica por la penetración de cámaras durante la década de los ochenta en Chile. Según postula Zuzana M. Pick, la importación masiva de productos extranjeros resultó nociva para la cultura nacional chilena, pero el acceso a tecnologías versátiles —como la vídeocamara portátil y el Super-8 - fue irónicamente beneficioso para la producción opositora al régimen, muchas veces clandestina ${ }^{51}$. En relación a estas apropiaciones $\mathrm{y}$ «usos desviados» de los excedentes de mercado, J acqueline Mouesca detalla

[50] Patrick Blaine, «Representing Absences in the Postidictatorial Documentary Cinema of Patricio Guzmán» (Latin American Perspectives, issue 188 , vol. 40, n. $\stackrel{-}{1}$, enero de 2013), p. 115.

[51] Zuzana M. Pick, «Chilean Documentary: Continuity and Disjunction», p. 125. 


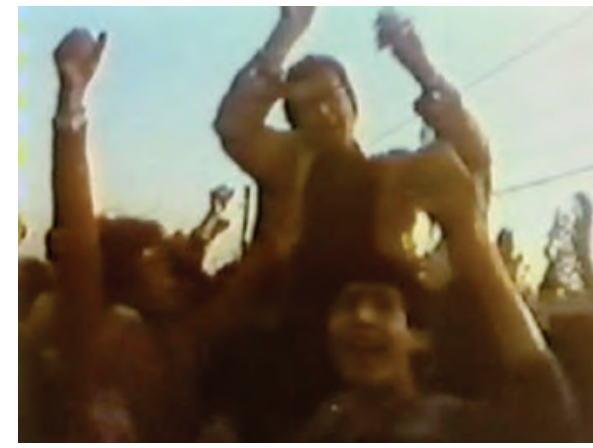

En nombre de Dios.

[52] Jacqueline Mouesca, El documental chileno, p. 79.

[53] Antonio Traverso y Germán Liñero Arend, «Chilean Political Documentary Video in the 1980s», en Vinicius Navarro y Juan Carlos Rodríguez (eds.), New Documentaries in Latin America (Nueva York, Palgrave Macmillan, 2014); Germán Liñero Arend, Apuntes para una historia del vídeo en Chile (Santiago, Ocho Libros Editores, 2010).

[54] Germán Liñero Arend, Apuntes para una historia del vídeo en Chile, p. 42.

[55] Para un detalle de las actividades de contrainformación que tuvieron un apoyo en el vídeo U-matic, véase Germán Liñero Arend, Apuntes para una historia del video en Chile.

[56] Patricio Guzmán, citado por J acqueline Mouesca, El documental chileno, p. 79.

[57] Antonio Traverso y Germán Liñero Arend, «Chilean Political Documentary Video in the 1980s», en Vinicius Navarro y J uan Carlos Rodríguez (eds.), New Documentaries in Latin America (Nueva York, Palgrave Macmillan, 2014).

[58] Entre otras iniciativas, Silva Henríquez impulsó Pro Paz (Comité de Cooperación para la Paz). que entre 1980 y 1983 se dio una suerte de boom de la producción de vídeo documental en Chile ${ }^{52}$. Según exponen Germán Liñero Arend y Antonio Traverso, la posesión de equipos U-matic -más accesibles en términos económicos y de saberes necesarios para su utilizaciónen manos de productores independientes favoreció el desarrollo de experiencias de registro y la conformación de un nutrido archivo con imágenes que los medios oficiales no mostraban, aportando un plus a la batalla audiovisual de los ochenta ${ }^{53}$. Estos factores fueron determinantes en la búsqueda por «registrar la realidad en forma subversiva» ${ }^{54}$, influyendo en la organización de redes de producción y distribución alternativas -muchas veces en colaboración con la Iglesia católica-, la creación de noticieros contrainformativos como Teleanálisis y la conformación de variados grupos de producción disidentes -entre ellos, Fasic, Cámara en mano, Ictus TV, Grupo Proceso- ${ }^{55}$. El rol del vídeo también es destacado por el propio Patricio Guzmán, quien sostiene que dicho dispositivo fue para los cineastas «el medio imprescindible de reencuentro con sus espectadores naturales», pero también «uno de los factores más importantes del combate informativo contra la cúpula militar» ${ }^{56}$.

Este aprovechamiento del dispositivo analógico, potenciado por la coyuntura política, se irá atenuando después de concluida la dictadura chilena. Tal como explican Traverso y Liñero Arend, la mayoría de los grupos de intervención política ligados al vídeo irá desapareciendo con el retorno democrático. Su innovación en lo que respecta al lenguaje visual y narrativo, su producción ligada a los movimientos sociales, así como sus estrategias de distribución y exhibición -que habían definido a toda una generación de documentalistas en los ochenta - tendrá un impacto menor en la cultura cinematográfica que se volverá predominante con el regreso a Chile de los directores exiliados ${ }^{57}$.

b) En nombre de Dios asigna un lugar destacado en el relato a los testimonios de miembros de la Iglesia de distintas jerarquías, los cuales manifiestan su desacuerdo con el régimen de Pinochet y su apoyo a la causa popular. Desde el punto de vista formal, estos testimonios - generalmente tomados en planos medios por una cámara estática—contrastan ampliamente con las vertiginosas escenas de resistencia descritas más arriba, imponiendo un notable cambio de ritmo. Pero, más allá de estos rasgos generales, el contenido de estos testimonios condensa muchas veces una fuerte carga dramática, ya sea por la contundencia de los juicios vertidos, por remitirse a situaciones álgidas o por el compromiso que demuestran estos religiosos a través de sus acciones de lucha. Esta perspectiva se observa claramente en las gestiones promovidas por la Vicaría de la Solidaridad —descritas más arriba-, en la palabra del cardenal Raúl Silva Henríquez - figura celebre en Chile por su compromiso y su actividad contra la dictadura $-{ }^{58}$ y en otras actividades respaldadas por miembros de la iglesia. 
Entre las iniciativas a favor de los derechos humanos gestionadas por miembros de la iglesia, se destacan las acciones contra la tortura lideradas por el teólogo J osé Aldunate. El testimonio de este último describe cómo se fueron materializando estas intervenciones en la vía pública, que tuvieron como propósito evidenciar frente a la opinión pública chilena distintos centros de detención en los cuales se habría practicado la tortura. Estas iniciativas eran planificadas como actividades de corta duración, puesto que la idea era darles finalización antes de la llegada de los carabineros. Junto con las declaraciones de Aldunate, el film presenta imágenes de registro que exhiben las intervenciones relámpago en la vía pública, las cuales incluían la denuncia a través de enormes carteles con la leyenda «aquí se tortura» y el canto de himnos. Siguiendo con la lógica habitual del film, estas imágenes de resistencia serán seguidas por otras en las que toma cuerpo la represión policial.

Además de narrar el modo en que muchos de los sacerdotes fueron amenazados y/ o resultaron víctimas de distintos actos de violencia, algunas de las declaraciones de estos párrocos cuestionan la religiosidad de la cúpula militar — poniendo en duda su efectiva cristiandad-y defienden la lucha social del pueblo. Uno de los testimonios más contundentes en este sentido probablemente sea el del Obispo Tomás González, quien sostiene la necesidad de matizar la frase «toda la violencia provenga de donde provenga, es mala», avalan-

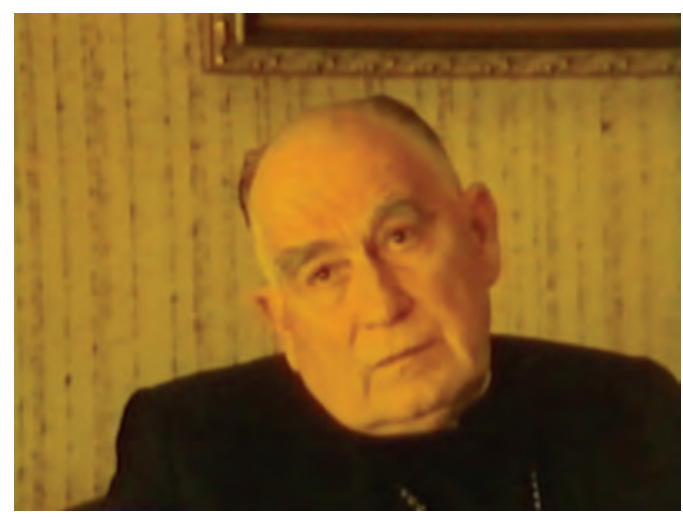

En nombre de Dios. do, de este modo, la resistencia popular armada y condenando, al mismo tiempo, aquella proveniente del Estado.

\section{A modo de conclusión}

Después de este recorrido, notamos que, más allá de las evidentes disidencias en lo que se refiere al rol de la Iglesia católica en Argentina y en Chile, saltan a la vista las diferenciadas modalidades que habría asumido el régimen dictatorial en uno y otro país. La forma clandestina que adoptó como característica distintiva el terrorismo de Estado en Argentina - situación que lo separa de los totalitarismos que se vivieron paralelamente en otros países latinoamericanos-, posiblemente haya influido en los regímenes de visibilidad e invisibilidad de la violencia y la protesta en la vía pública. Tal como sostiene Emilio Crenzel, «la clandestinidad procuraba evitar las denuncias de la comunidad internacional que recibía la dictadura chilena y permitía extender sin límites la tortura y eliminar a los opositores sin obstáculos legales o políticos» ${ }^{59}$. Este aspecto se expresa, entre otras múltiples consecuencias, en la carencia de imágenes de archivo sobre la resistencia y la represión en las calles durante los

[59] Emilio Crenzel, La historia política del Nunca Más. La memoria de las desapariciones en la Argentina, p. 33. 
[60] Tengamos en cuenta que por aquel entonces el Instituto Nacional de Cinematografía (INC) solamente subsidiaba films realizados o transferidos a $35 \mathrm{~mm}$ y las salas de cine solamente proyectaban películas en formato fílmico.

[61] Michael Chanan, The Politics of Documentary (Londres, British Film Institute, 2007), p. 259. años de dictadura en Argentina. El cine de intervención política durante aquellos años tendió a ser gestionado mayormente desde el exilio —como evidencia el caso de Todo es ausencia-, encontrando luego una circulación sumamente reducida en Argentina durante las dos décadas siguientes. En Chile, donde los acontecimientos políticos y la acción del régimen de Pinochet adoptaron una modalidad pública, la resistencia y las acciones de represión también cobraron una gran visibilidad, reproduciéndose a su vez en una multiplicidad de medios alternativos y contrainformativos que circularon a escala mundial y, en forma clandestina, en el interior del país cordillerano. Estos factores han influido en la existencia de un vasto repertorio de archivo sobre la resistencia chilena en las calles, junto con la implacable represión militar. Estos elementos se exacerban si tenemos en cuenta la penetración de dispositivos de captura de imágenes - fundamentalmente el vídeo-durante los años ochenta en Chile, los cuales han potenciado las vías de expresión y denuncia a través de las imágenes. Por el contrario, Argentina, durante la misma década, transitaba ya al retorno democrático, y el vídeo ya no tendría el mismo impacto en la lucha política audiovisual. A su vez, su utilización tenderá a ser resistida por una nueva generación de documentalistas que lo rechazará por su precariedad estética inicial —que no alcanzaba estándares broadcast—pero también debido a las dificultades institucionales que implicaba dicho formato, en un campo de producción que buscaba institucionalizarse ${ }^{60}$.

Entre algunos de los aspectos que comparten estos documentales, podemos notar que ambos tienen como característica común el trabajo sobre la coyuntura, sin mediar el paso del tiempo en la construcción de una perspectiva de abordaje y análisis. Por ese motivo, las temáticas que tratan tienden a fusionar un tiempo presente y un pasado tan próximo como problemático. Si Todo es ausencia se posiciona hacia el comienzo del retorno democrático, mirando hacia un pasado irresuelto que es difícil separar del presente, En nombre de Dios se zambulle de lleno en el horror de la dictadura en tiempo presente, nutriéndose, por momentos, de material de registro y de metraje de archivo que corresponde a un pasado sumamente próximo, correspondiente a acontecimientos que siguen repitiéndose en el presente del film. En lo que respecta a la producción de imágenes de registro, la represión significó en Chile la acumulación de un caudal de archivo de una inmensa variedad, mientras que en Argentina, la clandestinidad de la acción militar borró u ocultó del mapa visual la mayor parte de indicios sobre la violencia. Sin embargo, Todo es ausencia logra muy tempranamente seguir la acción de Madres y Abuelas de Plaza de Mayo tanto en Argentina como a nivel mundial, dejando un margen de registro muy valorable sobre su lucha. En ese sentido, podemos plantear que ambos documentales contienen un caudal de imágenes sobre la dictadura y las acciones de resistencia de un inconmensurable valor, contribuyendo, en potencia, a la organización de un archivo audiovisual de su época; lo cual, siguiendo a Michael Chanan, constituye un sitio potencial de interacción entre historia y memoria pública ${ }^{61}$. 
Otra característica común entre estos films remite a que ambos se apoyan, en gran medida, en el testimonio: en el caso de Todo es ausencia, fundamentalmente de las víctimas del terrorismo de Estado; en el caso de En nombre de Dios, a estos se suman los de distintos miembros de la Iglesia católica. De ese modo, un recurso tan convencional es utilizado en estos documentales como medio para comunicar iniciativas y prácticas que no lo son en absoluto. Así, las «cabezas parlantes» consideradas habitualmente como un indicio de falta de creatividad en el documental, pasan a evidenciar en este contexto, «... el potencial expresivo, ético y activista del testimonio audiovisual para promover los derechos humanos y las iniciativas de justicia transicional» ${ }^{62}$. Si en el caso del film de Kuhn el testimonio sirve para poner en discurso aquel horror que había sido silenciado durante los años de dictadura en Argentina, en el documental de Guzmán el dispositivo testimonial evidencia el modo en que prácticas esencialmente tradicionales como las religiosas habrían promovido en el Chile de los setenta y ochenta una gran ruptura, abriendo un aval para la disidencia, la protesta y la resistencia al régimen militar.

\section{BIBLIOGRAFÍA}

Aguilar, Gonzalo, Más allá del pueblo. Imágenes, indicios y políticas del cine (Buenos Aires, Fondo de Cultura Económica, 2015).

APreA, Gustavo, «Los usos de los testimonios en los documentales audiovisuales argentinos que reconstruyen el pasado reciente», en Gustavo Aprea (comp.), Filmar la memoria. Los documentales audiovisuales y la re-construcción del pasado (Los Polvorines, Universidad Nacional de General Sarmiento, 2012), pp. 121-152.

-, «El lugar de los testimonios en los documentales argentinos contemporáneos», en Actas del V Congreso Nacional sobre Problemáticas Sociales Contemporáneas (Santa Fe, Facultad de Humanidades y Ciencias de la Universidad Nacional del Litoral, 2008).

BLAINE, Patrick «Representing Absences in the Postidictatorial Documentary Cinema of Patricio Guzmán» (Latin American Perspectives, issue 188, vol. 40, n.o 1, enero de 2013), pp. 114-130.

Blaustein, Eduardo y Zubieta, Martín, Decíamos ayer. La prensa argentina bajo el Proceso (Buenos Aires, Colihue, 1998).

CALveiro, Pilar, Política y/ o violencia. Una aproximación a la guerrilla de los años 70 (Buenos Aires, Grupo Editorial Norma, 2005).

CAMpo, J avier, Batallas estéticas reales. Tendencias formales y temáticas en el cine documental político argentino (1968-1989), (Tesis Doctoral, Buenos Aires, Universidad de Buenos Aires, 2014).

CARVAJAL, Fernanda y Vindel, J aime, «Acción relámpago», en Perder la forma humana. Una imagen sísmica de los años ochenta en América Latina (Madrid, Museo Nacional Centro de Arte Reina Sofía, 2014).

Catoggio, María Soledad, Los desaparecidos de la iglesia. El credo contestatario frente a la dictadura (Buenos Aires, Siglo Veintiuno Editores, 2016).
[62] Bhaskar Sarkar y Janet Walker, «Introduction. Moving Testimonies», p. 2. 
Chanan, Michael, The Politics of Documentary (Londres, British Film Institut, 2007).

CRENZEL, Emilio, La historia política del Nunca más. La memoria de las desapariciones en la Argentina (Buenos Aires, Siglo Veintiuno Editores, 2008).

Díaz López, Marina, «Patricio Guzmán», en Paulo Antonio Paranaguá (ed.), Cine documental en América Latina (Madrid, Cátedra, 2003).

Elena, Alberto y Mestman, Mariano, «Para un observador lejano: el documental latinoamericano en España», en Paulo Antonio Paranaguá (ed.), Cine documental en América Latina (Madrid, Cátedra, 2003), p. 91.

Feld, Claudia, Del estrado a la pantalla. Las imágenes del juicio a los ex comandante en Argentina (Madrid, Siglo Veintiuno Editores, 2002).

-, «"Aquellos ojos que contemplaron el límite”: la puesta en escena televisiva de testimonios sobre la desaparición», en Claudia Feld y J essica Stites Mor (comps.), El pasado que miramos. Memoria e imagen ante la historia reciente (Buenos Aires, Paidós, 2009), pp. 77-109.

-, y Franco, Marina, «Introducción», en Claudia Feld y Marina Franco (dirs.), Democracia, hora cero: actores, políticas y debates en los inicios de la posdictadura (Buenos Aires, Fondo de Cultura Económica, 2015), pp. 9-21.

Felman, Shoshana, «Education and Crisis», en Cathy Caruth (ed.), Trauma: Explorations in Memory (Baltimore, The J ohns Hopkins University Press, 1995).

Franco, Marina, «"La teoría de los dos demonios" en la primera etapa de la posdictadura», en Claudia Feld y Marina Franco (dirs.), Democracia, hora cero: actores, políticas y debates en los inicios de la posdictadura (Buenos Aires, Fondo de Cultura Económica, 2015), pp. 23-80.

JeLIN, Elizabeth, Los trabajos de la memoria (Buenos Aires, Siglo XXI, 2002).

KAPLAN, Temma, Taking Back the Streets. Women, Youth, and Direct Democracy (Berkeley, Los Angeles y Londres, University of California Press, 2004).

LiÑERo AREND, Germán, Apuntes para una historia del vídeo en Chile (Santiago, Ocho Libros Editores, 2010).

Longoni, Ana, Tapia, Mabel, López, Miguel, Nogueira, Fernanda, Mesquita, André, Vindel, J aime y CARVAJAL, Fernanda, «Introducción. Perder la forma humana. Una imagen sísmica de los años ochenta», en Perder la forma humana. Una imagen sísmica de los años ochenta en América Latina (Madrid, Museo Nacional Centro de Arte Reina Sofía, 2014).

Mestman, Mariano, «Al compás de la revuelta. J orge Denti más allá del cine y la televisión», en Catálogo del XI Festival DerHumAlc, Cine de Derechos Humanos (Buenos Aires, FICDH, 2009).

Montecino, Sonia, «Dimensiones simbólicas del accionar político y colectivo de las mujeres en Chile. Una propuesta de lectura desde la construcción simbólica del género», en L. Luna y M. Vilanova Sims, Desde las orillas de la política. Género y poder en América Latina (Barcelona, Universidad de Barcelona, 1996), pp. 101-116. MouescA, J acqueline, El documental chileno (Santiago de Chile, LOM Ediciones, 2005). Palacios, J osé Miguel, «Chilean Exile Cinema and its Homecoming Documentaries», en Rebecca Prime (ed.), Cinematic Homecomings. Exile and Return in Transnational Cinema (Nueva York \& Londres, Bloomsbury, 2015), pp. 147-168.

PIck, Zuzana M., «Chilean Cinema in Exile, 1973-1986», en Michael T. Martin (ed.), Latin American Cinema, volume 2 (Detroit, Wayne State University Press, 1997), pp. 423-440. 
-, «Chilean Documentary: Continuity and Disjunction», en J ulianne Burton (ed.), The Social Documentary in Latin America (Pittsburgh, University of Pittsburgh Press, 1990), pp. 109-130.

RuffinelLi, J orge, El cine de Patricio Guzmán. En busca de las imágenes verdaderas (Santiago de Chile, Uqbar editores, 2008).

SARKAR, Bhaskar y WaLKer, Janet, «Introduction. Moving Testimonies», en Bhaskar Sarkar y J anet Walker (eds.), Documentary Testimonies. Global Archives of Suffering (Nueva York y Oxon, Routledge, 2010).

Traverso, Antonio, «Dictatorship Memories: Working through Trauma in Chilean Postdictatorship Documentary», (Continuum: J ournal of Media \& Cultural Studies, vol. 24, n..$^{\circ}$ 1, febrero de 2010), pp. 179-191.

- y LiÑero Arend, Germán, «Chilean Political Documentary Video in the 1980s», en Vinicius Navarro y Juan Carlos Rodríguez (eds.), New Documentaries in Latin America (Nueva York, Palgrave Macmillan, 2014).

WALKER, J anet, «Rights and Return: Perils and Fantasies of Situated Testimony after Katrina», en Bhaskar Sarkar y J anet Walker (eds.), Documentary Testimonies. Global Archives of Suffering (Nueva York y Oxon, Routledge, 2010).

Zylberman, Lior, Estrategias narrativas de un cine postdictatorial. El genocidio en la producción cinematográfica argentina (1984-2007), (Tesis de Maestría en Comunicación y Cultura, Facultad de Ciencias Sociales, Universidad de Buenos Aires, 2011). 